\begin{tabular}{|c|l|}
\hline Title & Resistance to Oncogenic Transformation in Revertant R1 of Human ras Transformed NIH 3T 3 cells \\
\hline Author(s) & $\begin{array}{l}\text { Kuzumaki, Noboru; Ogiso, Y oshifumi; Oda, A tsushi; Fujita, Hisakazu; Suzuki, Hiroaki; Sato, Chiharu; Mullauer, } \\
\text { Leonhard }\end{array}$ \\
\hline Citation & Molecular and Cellular Biology, 9(5), 2258 2263 \\
\hline Issue Date & 1989 \\
\hline Doc URL & http://hdl.handle.net/2115/753 \\
\hline Rights & Copyright (c) 1989 A merican Society for Microbiology \\
\hline Type & article (author version) \\
\hline File Information & NK89Kuz.pdf \\
\hline
\end{tabular}

Instructions for use 


\title{
Resistance to Oncogenic Transformation in Revertant R1 of Human ras-Transformed NIH 3T3 cells
}

\author{
NOBORU KUZUMAKI, YOSHIFUMI OGISO, ATSUSHI ODA, HISAKAZU FUJITA,
} HIROAKI SUZUKI, CHIHARU SATO, AND LEONHARD MULLAUER

\begin{abstract}
A flat revertant, R1, was isolated from human activated c-Ha-ras-1 (hu-ac-Ha-ras) gene-transformed NIH 3T3 cells (EJ-NIH 3T3) treated with mutagens. R1 contained unchanged transfected hu-ac-Ha-ras DNA and expressed high levels of hu-ac-Ha-ras-specific mRNA and p21 protein. Transfection experiments revealed that NIH 3 T3 cells could be transformed by DNA from R1 cells but R1 cells could not be retransformed by Kirsten sarcoma virus, DNA from EJ-NIH 3T3 cells, hu-ac-Ha-ras, V-src, v-mos, simian virus 40 large $\mathrm{T}$ antigen, or polyomavirus middle $\mathrm{T}$ antigen. Somatic cell hybridization studies showed that $\mathrm{R} 1$ was not retransformed by fusion with NIH 3T3 cells and suppressed anchorage independence of EJ-NIH 3T3 and hu-ac-Ha-ras gene-transformed rat W31 cells in soft agar. These results suggest that the reversion and resistance to several oncogenes in R1 is due not to cellular defects in the production of the transformed phenotype but rather to enhancement of cellular mechanisms that suppress oncogenic transformation.
\end{abstract}

\section{INTRODUCTION}

It has been found that 10 to $20 \%$ of human tumors have a mutation in one of the three ras oncogenes (Ha-ras, Ki-ras and N-ras) leading to the production of p21 ras oncoproteins, which are thought to play an important role in the transformed phenotype (1). The ras proteins bind GTP and GDP and have intrinsic GTPase activity. They may control cell proliferation by regulating a signal transduction pathway as do the regulatory $G$ proteins (1). However, the biochemical mode of action and the biological target molecules of the ras proteins are unknown. Recently, the activating mutations of the ras genes have been detected not only in malignant tumors such as colorectal tumors but also in benign tumors such as colon adenomas $(3,9)$. The former showed somatic loss of chromosome sequences, but the latter did not (8). Such chromosomal changes as monosomy or trisomy were also described in hamster cells transfected with v-Ha-ras or human activated c-Ha-ras-1 (hu-ac-Ha-ras) genes $(23,31)$. All of these findings suggest that ras activation is not sufficient and that alteration of cellular transformation suppressor genes is necessary for malignant transformation of cells. However, little is known about the suppressor genes or their products. Isolation of mutant cells that contain alterations in one or more of the suppressor genes involved in transformation by oncogenes could be one approach to this problem. 


\section{METHODS, RESULTS, AND DISCUSSION}

The EJ-NIH 3T3 cell line, which is an NIH 3T3 cell line carrying the transfected hu-ac-Ha-ras sequence of EJ human bladder carcinoma cells, kindly provided by T. Y. Shih (National Cancer Institute, Frederick, Md.; 34) showed the typical morphology of transformed cells. EJ-NIH 3 T3 cells $\left(10^{6}\right)$ were treated with ethyl methanesulfonate $(200 \mu \mathrm{g} / \mathrm{ml}$ for $24 \mathrm{~h})$ and 8-azaguanine $(5 \mu \mathrm{g} / \mathrm{ml})$. Two mutant clones, R1 and R2, were selected from the population. They showed a flat, typical spindle shape and an ordered growth pattern of fibroblast or endothelial cells. They had lost the ability to pile up at random and became contact inhibited or were arranged in oriented, hairlike arrays. R1 appeared even flatter than NIH 3T3 cells (Fig. 1). Growth of R1 cells was compared with that of EJ-NIH 3T3 cells in vitro. With cultures of 105 cells in Dulbecco modified Eagle medium with 10\% fetal calf serum (FCS), population doubling times of $\mathrm{NIH} 3 \mathrm{~T} 3$ and EJ-NIH 3T3 were 19 and $17 \mathrm{~h}$, respectively. These values were greatly increased, to $27 \mathrm{~h}$, in R1 (Table 1). EJ-NIH 3T3 cultured in 1\% FCS grew well, but R1 cells did not survive. Cell cycle analysis using computer-aided flow cytometry (Cytofluorograf; Ortho Diagnostics, Inc., Raritan, N.J.) revealed that R1 cells had a larger proportion of cells in GdG1, with a reciprocal decrease the proportion of cells in $S$ and G2/M phases in comparison with EJ-NIH 3T3 and even NIH 3T3 cells. Chromosome number was determined by the method of Oikawa et al. (21). Although NIH 3T3 and EJ-NIH 3T3 cells were hypotetraploid or triploid, R1 had hyperpentaploid karyotypes. It was found that $80 \%$ of EJNIH $3 \mathrm{~T} 3$ cells formed anchorage-independent colonies in soft agar containing 10\% FCS after 10 days of growth, whereas NIH 3T3 cells did not. R1 could not form colonies at all, even in soft agar containing $20 \%$ FCS after 20 days, which suggested that R1 was not simply a poor grower but had lost anchorage independence (Table 1). EJ-NIH 3 T3 cells $\left(10^{6}\right)$ injected subcutaneously into nine 2-day-old and nine adult syngeneic NIH Swiss mice (provided by T. Yamanouchi, Osaka University, Osaka, Japan) gave rise to tumors, and mean survival times were 15.0 and 38.4 days, respectively (Table 1). None of the 2-day-old or adult mice given injections of R1 or NIH 3T3 cells developed tumors, and they remained tumor free for at least 4 months. Transient treatment with cytidine analogs was reported to result in the transformation of some revertants (26). However, the R1 revertant was not transformed by such treatment $(0.1 \mu \mathrm{M} 5$-azacytidine). Furthermore, the $\mathrm{R} 1$ cell line has retained a flat morphology for more than 1 year, which indicates that it is a stable revertant.

Southern blot analysis (29) using pEJ6.6 (provided by R. A. Weinberg, Massachusetts Institute of Technology, Cambridge; 27 ) as a probe showed that DNAs from EJ-NIH 3T3 and R1 cells digested with BamHI had the characteristic 6.6-kilobase $(\mathrm{kb}) \mathrm{BamHI}$ fragment of the hu-ac-Ha-ras oncogene, whereas this fragment was not detected in NIH 3T3 cells (Fig. 2). We estimated that EJ-NIH 3T3 contained the hu-ac-Ha-ras-specific sequences (probably one transfected copy) and that the R1 cell population also retained the transfected hu-ac-Ha-ras sequence. Neither gross gene rearrangements nor amplifications of this gene were observed in the R1 cell line. Therefore, we also sought to determine whether there was any reduction in hu-ac-Ha-ras-specific RNA in the revertant, which might account for the loss of the transformed phenotype. Cytoplasmic RNA from NIH 3T3, EJ-NIH 3T3, and R1 lines was assayed by Northern (RNA) hybridization with the cloned probe specific for hu-ac-Ha-ras as described previously (22). R1 cells expressed high levels of 
1.5-kb-genome-size hu-ac-Ha-ras RNA (Fig. 3). On the other hand, no hybridization was detected with control NIH 3T3 RNA. All of the cell lines expressed similar amounts of 2.4-kb c-myc, 2.0-kb p53, and 2.2-kb cardiac actin transcripts, as determined by using probes MC413RC (provided by R. C. Gablo, National Cancer Institute, Bethesda, Md.; 7), pLTRp53cG (provided by M. Oren, Weizmann Institute of Science, Rehovot, Israel; 5), and pHRL83-BR (provided by P. Gunning, Stanford University School of Medicine, Stanford, Calif.; 12), respectively. The revertant cell properties might result from a discrete change in the resident myc gene or an analogous gene (14). However, our Northern analysis showed that the decreased expression of myc or p53 genes was not responsible for reversion of R1 cells.

Although ras transcripts of the correct size were found in the revertant cells at levels comparable to those in EJ-NIH 3T3 cells, this mRNA may be inefficiently translated. This would result in reduced intracellular levels of the p21 ras oncoprotein and the consequent loss of the transformed phenotype. All p21 ras proteins contain a covalently attached palmitic acid located in the C-terminal region (4). Lipidation of p21 is required for membrane association and transformation. Immunofluorescence studies with monoclonal antibody rp-28 (15) revealed that R1 cells expressed ras p21 protein in the same amount and localization as did EJ-NIH 3T3 cells, but NIH 3T3 cells showed weaker reactivity (Fig. 4a). None of these cells were stained with another monoclonal antibody, 3.5CMM, which reacts with a Rous sarcoma virus-induced tumor (16). These results suggested no abnormality in production or lipidation of ras p21 in the revertant cells. In addition, Western blot (immunoblot) analysis by a method described previously (15) showed that the level of p21 in EJ-NIH 3T3 and R1 cells was clearly higher than that of p21 in control NIH 3T3 cells and that the level of p21 correlated with the number of intact transcription units (Fig. 4b). Furthermore, there was no altered mobility of p21 in the Western blots in R1, which suggests that the suppression was not due to a remutation defect of the hu-ac-Ha-ras gene. The results of our analysis of p21 levels argues against reduced amounts of this protein as the cause of the loss of the transformed phenotype in the revertant R1.

Mouse NIH 3T3 cells $\left(3 \times 10^{5}\right)$ transfected by the calcium phosphate method (11) with DNA (20 to $40 \mu \mathrm{g}$ ) derived from EJ-NIH 3T3 cells carrying the hu-ac-Ha-ras gene displayed the transformed phenotype, with numerous transformed foci 21 days after transfection (Table 2). DNA extracted from R1 was also able to transform NIH 3T3 cells. The transformed cells contained the hu-ac-Ha-ras gene, as detected by Southern blot analysis (data not shown). On the other hand, DNA from NIH 3T3 showed few transformed foci. The oncogene in R1 cells was therefore biologically indistinguishable from the original hu-ac-Ha-ras transforming gene. Consequently, the $\mathrm{R} 1$ reversion event may have involved an alteration in cellular factors required for or suppressive of transformation, which resulted in the cells becoming resistant to transformation by the $\mathrm{p} 21$ protein.

To investigate these possibilities, we attempted to retransform the revertant cells by superinfection with Kirsten sarcoma virus (KiSV), which carries the v-Ki-ras oncogene, and by transfection with various transforming genes. The culture supernatant of mouse cell line M58-2T productively transformed by KiSV ( $10^{4}$ focus-forming units) (provided by N. Tsuchida, Tokyo Medical and Dental College, Tokyo, Japan; 33) was used as the virus source. When infected with KiSV, NIH 3 T3 cells had many foci whereas R1 cells yielded no detectable foci. KiSV-infected NIH 3T3 cells formed anchorage-independent colonies (70\% colony-forming ability) in soft agar, whereas KiSV-infected R1 cells formed no colonies. Southern analysis revealed that 
Hindlll-digested DNA from a KiSV-transformed nonproducer cell line, K234 (provided by N. Tsuchida; 33) contained the v-Ki-ras-specific 1.6-kb band probed with an EcoRI fragment of $\mathrm{HiHi} 3$ (provided by M. A. Gonda, National Cancer Institute, Frederick, Md.; 6), whereas DNAs from R1 and NIH 3T3 cells showed no such band (Fig. 5), in agreement with results reported previously (19). DNAs from both R1 and NIH 3T3 cell lines infected with KiSV had the 1.6-kb bands. This finding showed that the inability of KiSV to transform R1 cells was not due to inefficient infection of R1 cells.

Similar results were obtained when NIH 3T3 and R1 cells $\left(3 \times 10^{5}\right)$ were transfected by the calcium phosphate method (11) with DNAs from EJ-NIH 3T3 cells or hu-ac-Ha-ras (pEJ 6.6, $0.2 \mu \mathrm{g}$ ), v-src (pSVEneo-src, $10 \mu \mathrm{g}$; provided by A. Levinson, Genentech, Inc., South San Francisco, Calif.; 28), v-mos (pMSV-IL, $6.4 \mu$ g; provided by I. M. Verma, The Salk Institute; 35), and simian virus large T antigen (SV-ori- 8-16, $2.7 \mu \mathrm{g}$; provided by the Japanese Cancer Research Resources Bank and originally from Y. Gluzman, Cold Spring Harbor Laboratory, Cold Spring Harbor, N. Y.; 10). With DNAs from EJ-NIH 3T3 cells and all of the plasmids, NIH 3T3 cells formed transformed foci within 21 days after transfection, whereas R1 cells yielded no foci (Fig. 6). Transfection with $1 \mu \mathrm{g}$ of plasmid pSV2neo containing the Geneticin (G418, $200 \mu \mathrm{g} / \mathrm{ml}$; GIBCO Laboratories, Grand Island, N.Y.) resistant neo gene (provided by P. J. Southern, Scripps Clinic and Research Foundation, La Jolla, Calif.; 30) showed that the neo gene could be transferred and expressed in both NIH 3T3 and R1 cells, although with lower efficiency in the latter (Table 2, Fig. 6). These findings showed that the inability of hu-ac-Ha-ras and other transforming genes to transform R1 cells was not because of resistance of R1 cells to transfection. Furthermore, R1 cells could not be retransformed by polyomavirus middle T antigen DNA (provided by K. Fujinaga, Sapporo Medical College, Sapporo, Japan; 24) or by human activated c-hst and c-ret oncogenes (M. Kakinuma, personal communication). These results suggest that the R1 revertant cells are different from normal primary embryo cells and possess alterations in their cellular genomes that allow them to block transformation processes induced by v-Ki-ras, hu-ac-Ha-ras, v-src, v-mos, simian virus 40 large T antigen, polyomavirus middle $T$ antigen, and activated c-hst and c-ret genes at some common points distal to the initial interactions of their oncogene products with target molecules.

Theoretically, there are three classes of flat revertants from cells transformed by specific oncogenes. Those in the first class are induced by inactivation of the oncogenes. Those in the second class are induced by inactivation of cellular target genes $(13,20,25,32,37)$ or cooperating genes (14) required for transformation by a given oncogene. The third class of revertants results from activation of dominant transformation suppressor genes (18). In most cases, the flat revertants belong to the first class, and such revertants are not of great value in elucidating the mechanism of transformation (2). Fusion of the revertant cells with the untreated grandparental cells usually leads to restoration of the transformed state in the second class but not in the third class.

Some revertants of FBJ murine sarcoma virus (v-fos)- transformed Rat-i fibroblasts have sustained mutations in cellular genes and were found to be resistant to retransformation by v-fos, v-Ha-ras, v-abl, and v-mos but could be retransformed by the trk oncogene and polyomavirus middle $\mathrm{T}$ antigen (37). When the revertant clones were fused to untransformed cells, about $50 \%$ of the resulting hybrid colonies had transformed characteristics. However, the transformed phenotype was not 
reexpressed in progeny cells when $10^{6}$ G418- and 8-azaguaine-resistant R1 (neo R1) cells were fused with $10^{6}$ nontransformed NIH 3 T3 cells by using polyethylene glycol 1500 (Wako Pure Chemical Industries Ltd., Osaka, Japan). Neither neo R1 nor hybrid cells $\left(10^{4}\right)$ formed colonies in soft agar containing G418 $(200 \mathrm{pg} / \mathrm{ml})$ and HAT (hypoxanthine-aminopterin-thymidine; 17 ) in repeated experiments. In addition, when $10^{6}$ G418- and 8-azaguanine-resistant NIH 3T3 (neo NIH 3T3) or neo R1 cells were fused with $10^{6}$ EJ-NIH 3 T3 or hu-ac-Ha(EJ)- ras-transformed WKA-H rat embryo fibroblast W31 cells (36) and selected by G418 and HAT, 85\% of W31 cells formed colonies in soft agar containing normal medium (36), whereas none of neo NIH 3T3, EJ-NIH 3T3, and W31 cells did so in soft agar containing G418 and HAT. Hybridity of the fused cells (between neo NIH 3T3 or neo R1 and W31 cells) was confirmed by immunofluorescence with monoclonal antibodies $\mathrm{H}-2.64$ (detecting $\mathrm{H}-2 \mathrm{Lq}$ and $\mathrm{H}-2 \mathrm{Dq}$ of NIH Swiss mice; Litton Bionetics, Kensington, Md.) and FSX101.2F8 (detecting RTL.Ak of WKA-H rats; provided by T. Natori, Hokkaido University School of Medicine, Sapporo, Japan). Hybrid cells $\left(10^{4}\right)$ of neo NIH 3T3 cells and EJ-NIH 3T3 or W31 cells showed anchorage-independent colony formation (75 and 80\%, respectively) in soft agar containing G418 and HAT after 10 days of growth (Table 3). On the other hand, hybrid cells (104) of neo R1 cells and EJ-NIH 3T3 or W31 cells did not form colonies in soft agar containing G418 and HAT. These results show that the R1 revertant phenotype is dominant over the transformed phenotype and could be explained if R1 cells are activated in a mouse transformation suppressor gene(s) necessary for inhibition of the transformed phenotype mediated by hu-ac-Ha-ras and other transforming genes. A similar type of reversion of KiSV-transformed cells was described previously (18). However, the revertant cells $(\mathrm{C}-11)$ were resistant to the activities of $\mathrm{v}$-ras and $\mathrm{V}$-src but not to those of $\mathrm{v}$-mos or polyomavirus middle $\mathrm{T}$ antigen.

All of these findings suggest that the R1 revertant is unique and differs from previously reported revertants in several respects. Using two-dimensional gel electrophoresis, we recently found a unique protein with a molecular weight of 92,000 and pl of 5.7 that was detected in R1 and R2 cells but not in grandparental NIH 3T3 and parental EJ-NIH 3T3 cells (H. Fujita et al., manuscript in preparation). Further studies to determine an altered gene encoding the protein are in progress in our laboratory. Such studies would be useful in elucidating the cellular mechanism that suppresses oncogenic transformation.

\section{ACKNOWLEDGMENT}

This research was supported in part by a grant-in-aid for Cancer Research from the Ministry of Education, Science and Culture, Japan, and, a grant-in-aid from the Ministry of Health and Welfare for Comprehensive 10-Year Strategy for Cancer Control, Japan. We thank R. H. Bassin and G. Klein for helpful discussions.

\section{LITERATURE CITED}

1. Barbacid, M. 1987. ras genes. Annu. Rev. Biochem. 56:779-827. 2. Bassin, R. H., and M. Noda. 1987. Oncogene inhibition by 2262 NOTES

NOTES 2263 
cellular genes. Adv. Viral Oncol. 6:103-127. 3. Bos, J. L., E. R. Fearon, S. R. Hamilton, M. V.-de Vries, J. H. van Boom, A. J. van der Eb, and B. Vogelstein. 1987. Prevalence of ras gene mutations in human colorectal cancers. Nature (London) 327:293-297.

4. Buss, J. E., and B. M. Sefton. 1986. Direct identification of palmitic acid as the lipid attached to p2lras. Mol. Cell. Biol. 6:116-122.

5. Eliyahu, D., D. Michalovitz, and M. Oren. 1985. Overproduction of p53 antigen makes established cells highly tumorigenic. Nature (London) 316:158-160.

6. Ellis, R. W., D. DeFeo, T. Y. Shih, M. A. Gonda, H. A. Young, N. Tsuchida, D. R. Lowy, and E. M. Scolnick. 1981. The p21 src genes of Harvey and Kirsten sarcoma viruses originate from divergent members of a family of normal vertebrate genes. Nature (London) 292:506-510.

7. Favera, R. D., F. Wong-Staal, and R. C. Gallo. 1981. onc gene amplification in promyelocytic leukaemia cell line HL-60 and primary leukaemic cells of the same patient. Nature (London) 299:61-63.

8. Fearon, E. R., S. R. Hamilton, and B. Vogelstein. 1987. Clonal analysis of human colorectal tumors. Science 238:193-197. 9. Forrester, K., C. Almoguera, K. Han, W. E. Grizzle, and M. Perucho. 1987. Detection of high incidence of K-ras oncogenes during human colon tumorigenesis. Nature (London) 327:298- 303.

10. Gluzman, Y., R. J. Frisque, and J. Sambrook. 1980. Origindefective mutants of SV40. Cold Spring Harbor Symp. Quant. Biol. 44:293-300.

11. Graham, F. L., and A. J. Van der Eb. 1973. A new technique for the assay of infectivity of human adenovirus 5 DNA. Virology 52:456467.

12. Gunning, P., P. Ponte, L. Kedes, R. J. Hickey, and A. I. Skoultchi. 1984. Expression of human cardiac actin in mouse $L$ cells: a sarcomeric actin associates with a nonmuscle cytoskeleton. Cell 36:709-715.

13. Inoue, H., M. Yutsudo, and A. Hakura. 1983. Rat mutant cells showing temperature sensitivity for transformation by wild-type Moloney murine sarcoma virus. Virology 125:242-245. 14. Katz, E., and B. J. Carter. 1986. A mutant cell line derived from NIH/3T3 cells: two oncogenes required for in vitro transformation. J. Natl. Cancer Inst. 77:909-914.

15. Kuzumaki, N., A. Oda, S. Yamagiwa, N. Taniguchi, H. Kobayashi, and T. Oikawa. 1986. Establishment of four mouse hybridoma cell lines producing monoclonal antibodies reactive with ras oncogene product p21. J. Natl. Cancer Inst. 77: 1273-1279.

16. Kuzumaki, N., H. Minakawa, T. Miyazaki, S. Haraguchi, T. Matsuo, and T. 0. Yoshida. 1982. Individually distinct tumorspecific cell surface antigen identified by monoclonal antibody on a Rous sarcoma virus-induced mouse tumor. J. Natl. Cancer Inst. 69:527-530.

17. Littlefield, W. J. 1964. Selection of hybrids from matings of fibroblasts in vitro and their presumed recombinants. Science 145:709-710.

18. Noda, M., Z. Selinger, E. M. Scolnick, and R. H. Bassin. 1983. Flat revertants isolated from Kirsten sarcoma virus-transformed cells are resistant to the action of specific oncogenes. Proc. Natl. Acad. Sci. USA 80:5602-5606.

19. Norton, J. D., and R. J. Avery. 1984. Integration of proviral DNA in Kirsten murine sarcoma virus-infected mouse fibroblasts. J. Gen. Virol. 65:309-316.

20. Norton, J. D., F. Cook, P. C. Roberts, J. P. Clewley, and R. J. Avery. 1984. Expression of Kirsten murine sarcoma virus in transformed nonproducer and revertant $\mathrm{NIH} / 3 \mathrm{~T} 3$ cells: evidence for cell-mediated resistance to a viral oncogene in phenotypic reversion. J. Virol. 50:439-444. 
21. Oikawa, T., N. Kuzumaki, T. Yamada, I. Chiba, and S. Yamagiwa. 1987. Suppression of transformed phenotypes in intraspecific somatic cell hybrid clones between the c-myc activating mouse plasmacytoma line and normal cells. Int. J. Cancer 39:604-610.

22. Oikawa, T., Y. Yuhki, N. Kondoh, K. Abe, N. Yuhki, Y. Ogiso, and N. Kuzumaki. 1988. c-myc expression and transformed phenotypes in hybrid clones between mouse plasmacytoma S194 cells and normal spleen cells or fibroblasts. Int. J. Cancer 42:435-440.

23. Oshimura, M., T. M. Gilmer, and J. C. Barrett. 1985. Nonrandom loss of chromosome 15 in Syrian hamster tumours induced by v-Ha-ras plus v-myc oncogenes. Nature (London) 316: 636-639.

24. Rassoulzadegan, M., A. Cowie, A. Carr, N. Glaichenhaus, R. Kamen, and F. Cuzin. 1982. The roles of individual polyoma virus early proteins in oncogenic transformqtion. Nature (London) 300:713-718.

25. Sacks, T. L., E. J. Hershey, and J. R. Stephenson. 1979. Abelson murine leukemia virus-infected cell lines defective in transformation. Virology 97:231-240.

26. Samid, D., D. M. Flessate, and R. M. Friedman. 1987. Interferon- induced revertants of ras-transformed cells: resistance to transformation by specific oncogenes and retransformation by 5-azacytidine. Mol. Cell. Biol. 7:2196-2200. 27. Shib, C., and R. A. Weinberg. 1982. Isolation of a transforming sequence from a human bladder carcinoma cell line. Cell 29:161-169.

28. Snyder, M. A., J. M. Bishop, J. P. McGrath, and A. D. Levnnson. 1985. A mutation at the ATP-binding site of pp60v-src abolishes kinase activity, transformation, and tumorigenicity. Mol. Cell. Biol. 5:1772-1779.

29. Southern, E. M. 1975. Detection of specific sequences among DNA fragments separated by gel electrophoresis. J. Mol. Biol. 98:503-517.

30. Southern, P. J., and P. Berg. 1982. Transformation of mammalian cells to antibiotic resistance with a bacterial gene under control of the SV40 early region promoter. J. Mol. Appl. Genet. 1:327-341.

31. Stenman, G., E. 0. Delorme, C. C. Lau, and R. Sager. 1987. Transfection with plasmid pSV2gptEJ induces chromosome rearrangements in CHEF cells. Proc. Natl. Acad. Sci. USA 84:184-188.

32. Stephenson, J. R., R. K. Reynolds, and S. A. Aaronson. 1973. Characterization of morphologic revertants of murine and avian sarcoma virus-transformed cells. J. Virol. 11:218-222. 33. Tsuchida, N., M. Shih, R. V. Gilden, and M. Hatanaka. 1974. Mutants of nonproducer cell lines transformed by murine sarcoma virus. III. Detection and characterization of RNA specific for helper and sarcoma viruses. J. Exp. Med. 140:218-224. 34. Ulsh, L. S., and T. Y. Shih. 1984. Metabolic turnover of human c-rasH p21 protein of EJ bladder carcinoma and its normal cellular and viral homologs. Mol. Cell. Biol. 4:1647-1652. 35. Van Beveren, C., F. Van Straaten, J. A. Galleshaw, and I. M. Verma. 1981. Nucleotide sequence of the genome of a murine sarcoma virus. Cell 27:97-108.A

36. Yagihashi, A., N. Sato, T. Torigoe, M. Okubo, A. Konno, N. Takahashi, T. Yamashita, K. Fujinaga, N. Kuzumaki, and K. Kikuchi. 1988. Identification of the transformation-associated cell surface antigen expressed on the rat fetus-derived fibroblast. Cancer Res. 48:2798-2804.

37. Zarbl, H., J. Latreille, and P. Jolicoeur. 1987. Revertants of V-fos-transformed fibroblasts have mutations in cellular genes essential for transformation by other oncogenes. Cell 51:357-369. VOL. 9, 1989 


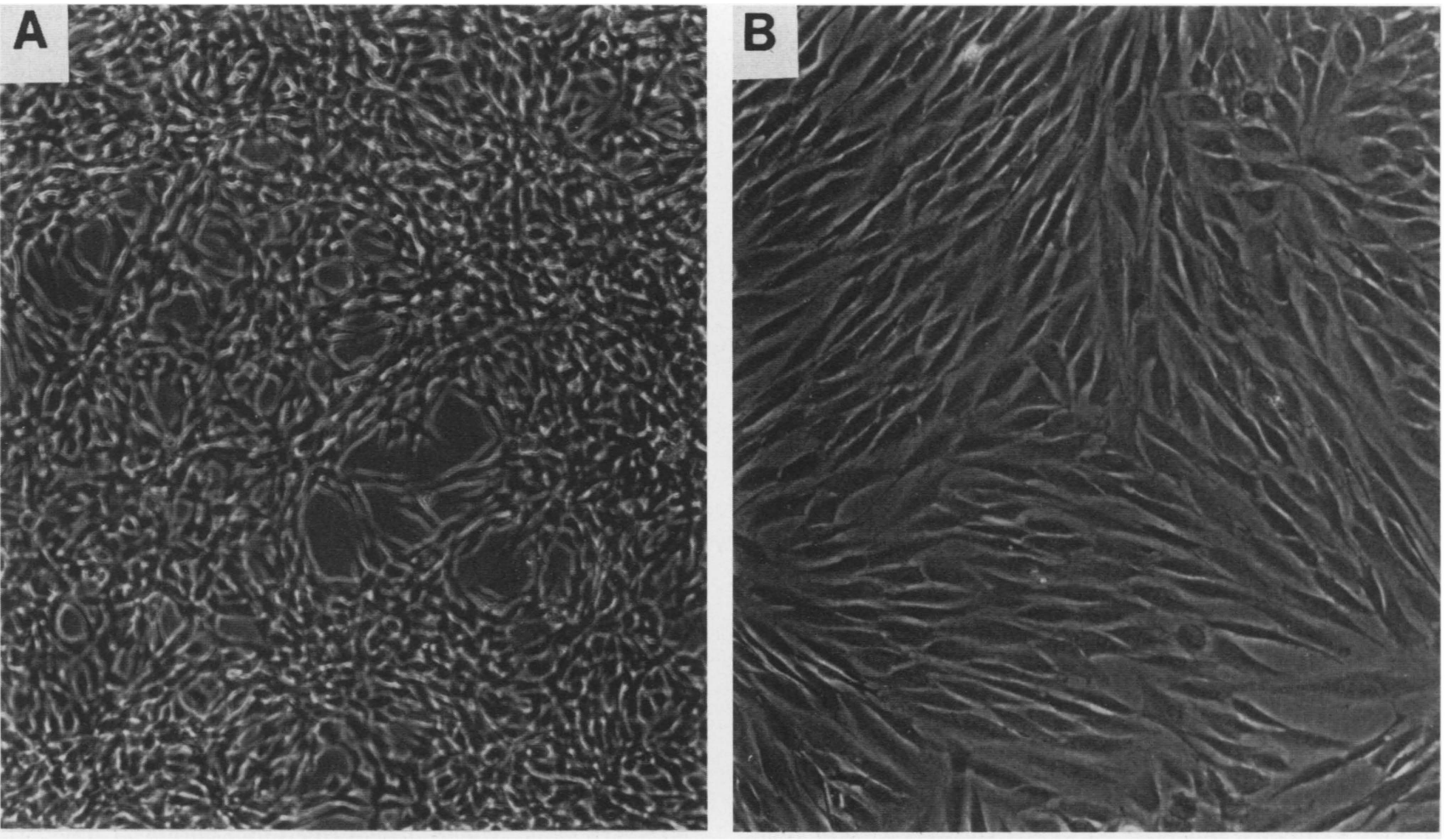

FIG. 1. Morphology of NIH 3T3 cells transformed by hu-ac-Ha-ras (EJ-NIH 3T3) (A) and of R1, a flat revertant derived from EJ-NIH 3T3 (B) Magnification, $\times 100$. 
TABLE 1. Growth properties of NIH 3T3, hu-ac-Ha-ras-transformed NIH 3T3 (EJ-NIH 3T3), and revertant R1 cells

\begin{tabular}{|c|c|c|c|c|c|c|c|c|c|c|}
\hline \multirow{3}{*}{ Cells } & \multirow{3}{*}{ Shape } & \multirow{3}{*}{$\begin{array}{l}\text { Growth } \\
\text { pattern }\end{array}$} & \multirow{3}{*}{$\begin{array}{l}\text { Doubling } \\
\text { time (h) }\end{array}$} & \multicolumn{4}{|c|}{ Property } & \multirow{3}{*}{$\begin{array}{c}\text { Colony- } \\
\text { forming } \\
\text { ability }(\%)^{b}\end{array}$} & \multirow{2}{*}{\multicolumn{2}{|c|}{ Tumorigenicity (MSD) ${ }^{c}$}} \\
\hline & & & & \multicolumn{3}{|c|}{ Growth phase (\%) } & \multirow{2}{*}{$\begin{array}{l}\text { Chromosome } \\
\text { no. }( \pm S D)\end{array}$} & & & \\
\hline & & & & $G_{0}+G_{1}$ & $\mathbf{S}$ & $\mathrm{G}_{2}+\mathrm{M}$ & & & Newborn & Adult \\
\hline NIH 3T3 & Flat & Ordered & 19 & 51 & 31 & 18 & $71 \pm 1.4$ & 0 & $0 / 9$ & $0 / 9$ \\
\hline EJ-NIH 3T3 & Rounded & Random & 17 & 34 & 53 & 13 & $60 \pm 1.1$ & 80 & $9 / 9(15.0)$ & $9 / 9(38.4)$ \\
\hline $\mathbf{R} 1$ & Flat & Ordered & 27 & 66 & 25 & 9 & $103 \pm 9.7$ & 0 & $0 / 9$ & $0 / 9$ \\
\hline
\end{tabular}

${ }^{a}$ Cells were plated at $10^{5}$ in Dulbecco modified Eagle medium containing $10 \%$ FCS.

${ }^{b}$ Cells were plated at $10^{4}$ in $0.3 \%$ soft agar with $10 \%$ FCS, and colony-forming ability was determined 10 days later.

c Cells were subcutaneously injected at $10^{6}$. MSD, Mean survival days. 


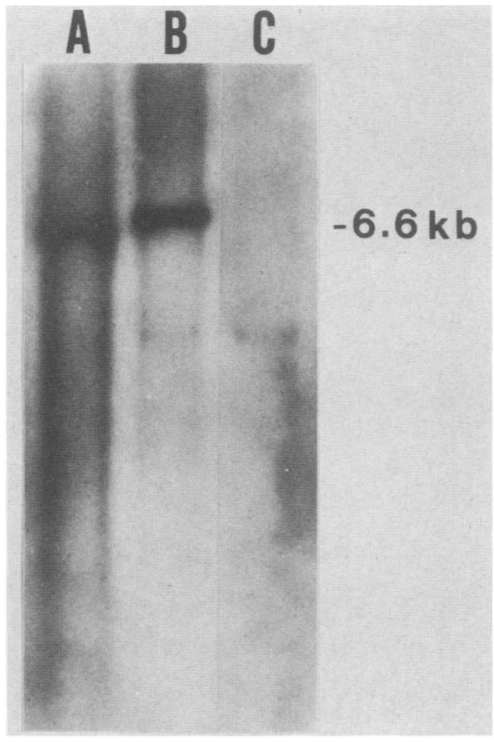

FIG. 2. Detection by Southern blotting of the hu-ac-Ha (EJ)-ras sequence in EJ-NIH 3T3 (A), R1 (B), and NIH 3T3 (C) cells. 


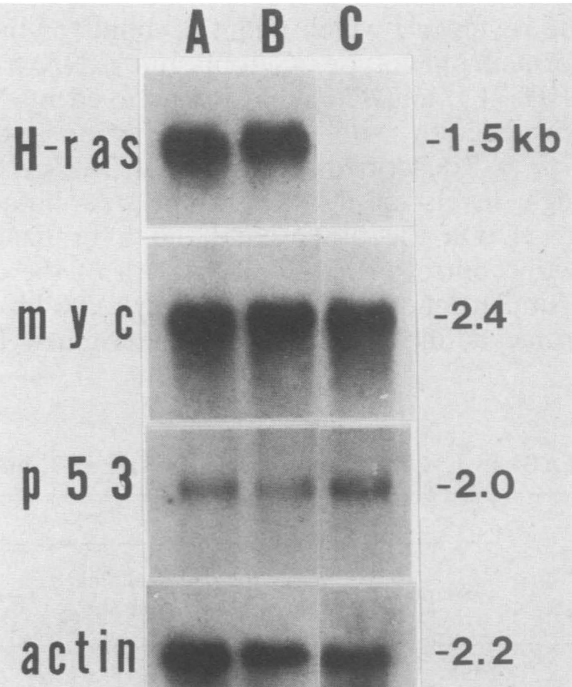

FIG. 3. Expression of hu-ac-Ha-ras- c-myc-, p53-, and cardiac actin-specific mRNAs in EJ-NIH 3T3 (A), R1 (B), and NIH 3T3 (C) cells (Northern blot). The same filter was used in this experiment. 

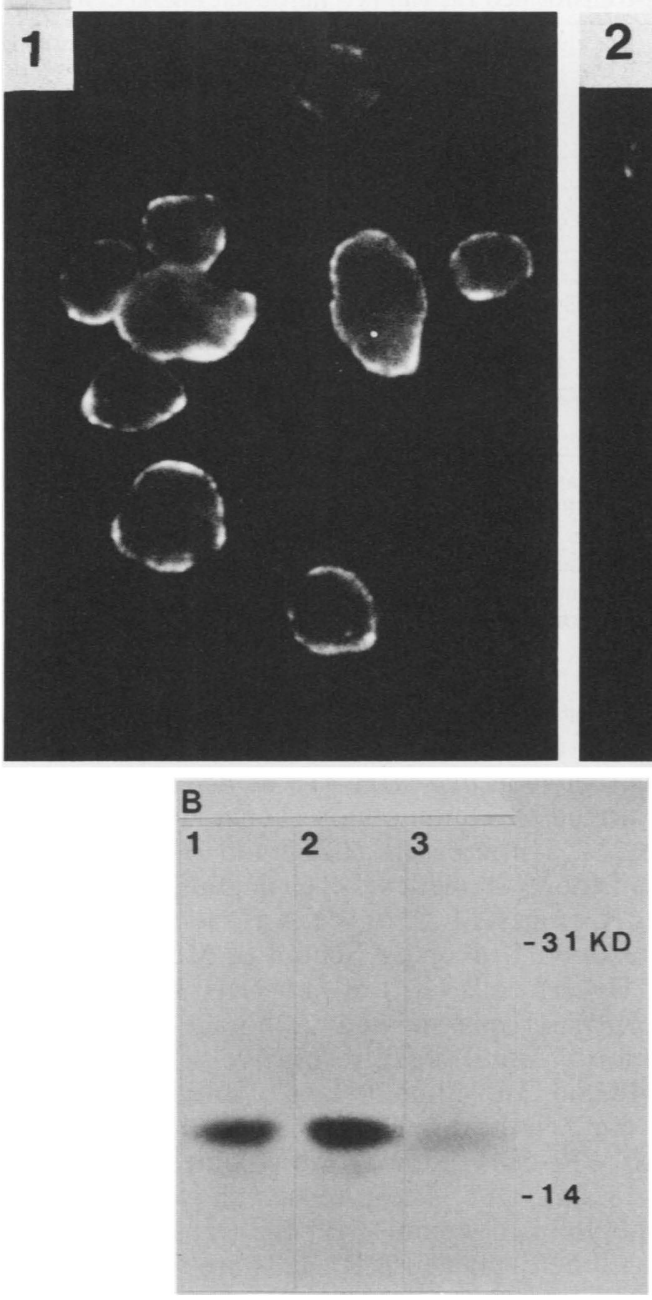
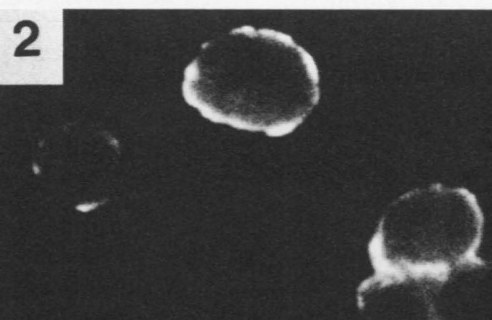

\section{3}

FIG. 4. Expression of p21 ras proteins analyzed by immunofluorescence (A) (magnification, $\times 376)$ and Western blot (B) in EJ-NIH 3T3 (1), R1 (2), and NIH 3T3 (3) cells. Monoclonal antibody rp-28 was used to specifically bind p21. Molecular size markers: carbonic anhydrase (31 kilodaltons) and RNase A (14 kilodaltons). 
FIG. 5. Detection of the v-Ki-ras sequence in KiSV-transformed nonproducer K234 (1), KiSV-infected R1 (2), uninfected R1 (3), KiSV-infected NIH 3T3 (4), and uninfected NIH 3T3 (5) cells. 
TABLE 2. Transfection analysis of various DNAs in NIH 3T3 and R1 cells

\section{Donor DNA}

No. of transformed foci (expt 1) or G418-resistant colonies (expt 2)/ $\mu \mathrm{g}$ of $\mathrm{DNA}^{a}$ in:

Expt 1

Cell type

EJ-NIH 3T3

R1

NIH 3T3

Plasmid

pEJ6.6 (hu-ac-Ha-ras)

pSVEneo-src (v-src)

pMSV-1L (v-mos)

SVori-8-16 (simian virus 40

large $T$ antigen)

Salmon sperm DNA

Expt 2

\section{pSV2neo}

Salmon sperm DNA
0.59
0.28
0.01

1,050

300

110

420

0

0

0

0

0

0

0

58

0
16

0

a A total of $3 \times 10^{5}$ cells were transfected, and foci or colonies were counted 21 days later. Data are means of two experiments. 


\section{H-ras}

V-s r C

V-mos

SV40T

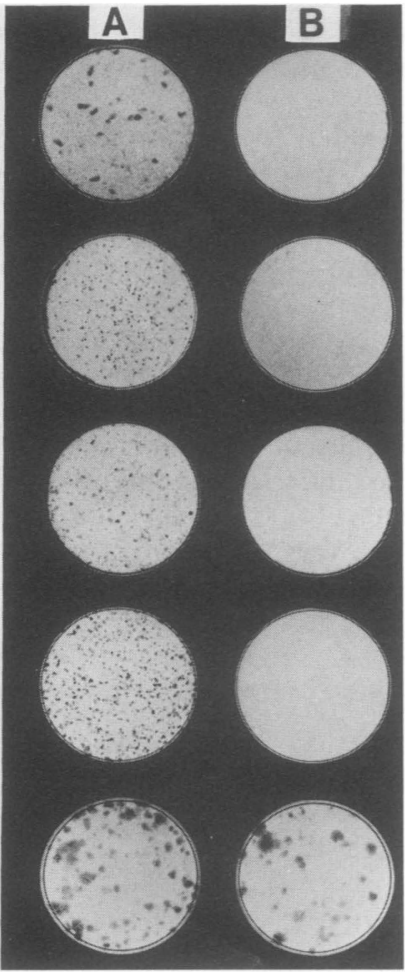

FIG. 6. Transforming and transfecting efficiencies of hu-ac-Haras $(0.2 \mu \mathrm{g})$, v-src $(10 \mu \mathrm{g}), \mathrm{v}$-mos $(6.4 \mu \mathrm{g})$, simian virus large $\mathrm{T}$ antigen (SV40T) $(2.7 \mu \mathrm{g})$, and neo (1 $\mu \mathrm{g})$ DNAs in NIH 3T3 (A) and R1 (B) cells. 
TABLE 3. Anchorage independence of hybrid cells obtained by fusion of R1 or NIH 3T3 cells with NIH 3T3, EJ-NIH 3T3, or huac-Ha-ras-transformed rat embryo fibroblast (W31) cells

Cell type

Colony-forming ability $^{a}(\%)$

\section{Parental}

neo $\mathrm{R} 1^{b}$

neo NIH 3T3 ${ }^{c}$.

EJ-NIH 3T3

$\mathrm{W} 31^{d}$.

Hybrid

neo R1 $\times$ NIH 3T3.

neo NIH 3T3 $\times$ EJ-NIH 3T3...

neo $\mathrm{R} 1 \times \mathrm{EJ}-\mathrm{NIH} 3 \mathrm{~T} 3$

neo NIH $3 \mathrm{~T} 3 \times \mathrm{W} 31$

neo $\mathrm{R} 1 \times \mathrm{W} 31$

${ }^{a}$ Cells were plated at $10^{4}$ in $0.3 \%$ soft agar containing $10 \%$ FCS and supplemented with G418 $(200 \mu \mathrm{g} / \mathrm{ml})$ and HAT. Colony-forming ability was determined 10 days later.

${ }^{b}$ G418- and 8-azaguanine-resistant $R 1$ cells.

c G418- and 8-azaguanine-resistant NIH 3T3 cells.

${ }^{d}$ Value for colony-forming ability in soft agar containing normal medium is $85 \%$ (35). 